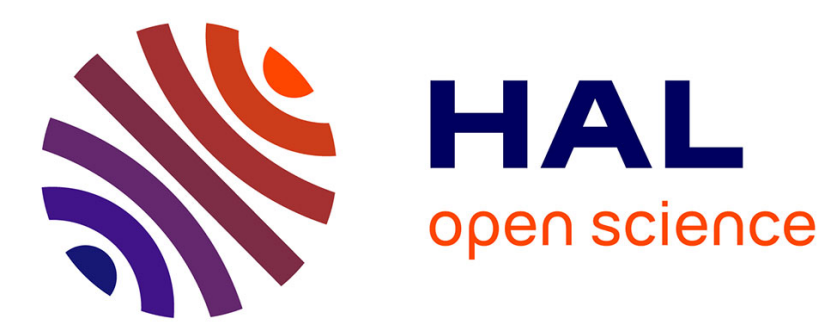

\title{
THE LOW TEMPERATURE TRANSITION IN MONOCLINIC PYRRHOTITE
}

\author{
G. Fillion, P. Rochette
}

\section{To cite this version:}

G. Fillion, P. Rochette. THE LOW TEMPERATURE TRANSITION IN MONO-

CLINIC PYRRHOTITE. Journal de Physique Colloques, 1988, 49 (C8), pp.C8-907-C8-908. 10.1051/jphyscol:19888412 . jpa-00228604

\section{HAL Id: jpa-00228604 https://hal.science/jpa-00228604}

Submitted on 1 Jan 1988

HAL is a multi-disciplinary open access archive for the deposit and dissemination of scientific research documents, whether they are published or not. The documents may come from teaching and research institutions in France or abroad, or from public or private research centers.
L'archive ouverte pluridisciplinaire HAL, est destinée au dépôt et à la diffusion de documents scientifiques de niveau recherche, publiés ou non, émanant des établissements d'enseignement et de recherche français ou étrangers, des laboratoires publics ou privés. 


\title{
THE LOW TEMPERATURE TRANSITION IN MONOCLINIC PYRRHOTITE
}

\author{
G. Fillion $\left({ }^{1}\right)$ and P. Rochette $\left({ }^{2}\right)$ \\ $\left.{ }^{1}\right)$ Laboratoire Louis Néel, C.N.R.S., 166X, 38042 Grenoble Cedex, France \\ (2) L.G.I.T., Observatoire de Grenoble, I.R.I.G.M., 68X, 38402 St Martin d'Hères Cedex, France
}

\begin{abstract}
It is confirmed by new magnetization measurements that a magnetic transition occurs sharply at $30 \mathrm{~K}$ in the monoclinic pyrrhotite $\mathrm{Fe}_{7} \mathrm{~S}_{8}$. Though its nature is not yet fully understood, this transition shows some similarities with the Verwey transition and can provide a powerful tool for the identification of pyrrhotite in rocks.
\end{abstract}

The properties of the monoclinic pyrrhotite $\mathrm{Fe}_{7} \mathrm{~S}_{8}$, especially its large magnetic anisotropy, are of great importance in geophysics, and the recent growing attention in paleomagnetism for its contribution to the remanent magnetization of rocks, brings to interest any unambiguous way of identification of this mineral.

The ferrimagnetism occurs in $\mathrm{Fe}_{7} \mathrm{~S}_{8}$ with vacancies ordering at $T_{\mathrm{N}}=590 \mathrm{~K}[1-4]$. The spontaneous magnetization $J_{s}$, which lies in the (001) plane above $200 \mathrm{~K}$, rotates progressively at low temperature toward the pseudohexagonal (001) $c$ axis, taking at helium temperature an intermediate direction at about $70^{\circ}$ from the $c$ axis [5]. A small discontinuity in the thermal variation of the magnetization has been suspected around $30 \mathrm{~K}$ and related to a kink in the electrical resistivity vs. $T$ curve $[6,7]$ and to a specific heat anomaly [8]. But, surprisingly, it has never been more studied and, until now, there is very few reliable data on the $\mathrm{Fe}_{7} \mathrm{~S}_{8}$ low temperature behaviour, especially below $80 \mathrm{~K}$.

Recently, the discovery of some anomalies at $30 \mathrm{~K}$ on the remanent magnetization of some pyrrhotite containing rocks, give a new strong interest to precise the magnetic behaviour of $\mathrm{Fe}_{7} \mathrm{~S}_{8}$ in this low temper-

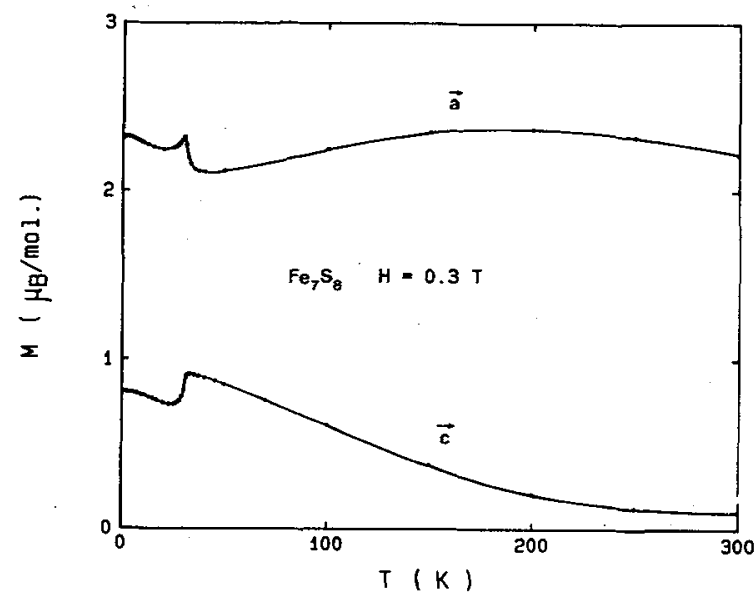

Fig. 1. - Magnetization at $0.3 \mathrm{~T}$, after saturation at $7 \mathrm{~T}$ for each temperature, of the $\mathrm{Fe}_{7} \mathrm{~S}_{8}$ single crystal. ature region. So we have undertaken new high resolution measurements on the same single crystal measured by Pauthenet and on some pyrrhotite-bearing black schists from the Alps, the Appalaches and the Himalaya. Only typical results are presented here and more details will be published elsewhere.

In the figure 1, the magnetization curves at constant magnetic field $(0.3 \mathrm{~T})$ show clearly both the components, along the hard $c$ axis and easy $a$ axis, having an important variation sharply confined in few Kelvins around $30 \mathrm{~K}$. These magnetization jumps are completely smeared out by fields greater than $3 \mathrm{~T}$, but become relatively more important as the field value is decreased.

When the crystal is cooled in zero field, the isothermal remanent magnetization acquired under $4 \mathrm{~T}$ at room temperature along the $a$ axis (RTS-IRM), exhibits also such a large jump at $30 \mathrm{~K}$, reversing its initial direction (Fig. 2a). A subsequent heating makes the RTS-IRM to recover its sign and partly its value at the same transition temperature.

The same measurement procedure has been performed on rock samples. with well characterized $\mathrm{Fe}_{7} \mathrm{~S}_{8}$ contents, using a variable temperature SQUID magnetometer [9]. For all of them, the observed RTS-IRM $(T)$ curves present similar steps in the narrow $30-34 \mathrm{~K}$ temperature range. An important recovery is always found but the self reversal phenomenon is absent. As typical example, the curve of the AP11 sample from Appalaches is reported in the figure $2 \mathrm{~b}$.

For the discussion, we can use the classical fourth order developpement of the magnetocrystalline energy with respect to the polar $(\theta)$ and azimutal $(\varphi)$ angles of the spontaneous magnetization vector $J_{\mathrm{s}}$, relative to the $c$ axis and the (001) plane $a$ axis. Above about $100 \mathrm{~K}$, the $K_{1}$ and $K_{2}$ constants of the $\varphi$-containing terms are clearly one order of magnitude smaller than the others, $K_{3}$ and $K_{4}$, and usually a separate analysis is made for the in-plane and out-of-plane anisotropies $[5-7,10]$. At lower temperature, the fact that the transition disappears at high fields, especially along the $c$ axis, permit us to assume that $K_{3}$ and $K_{4}$ keep high 


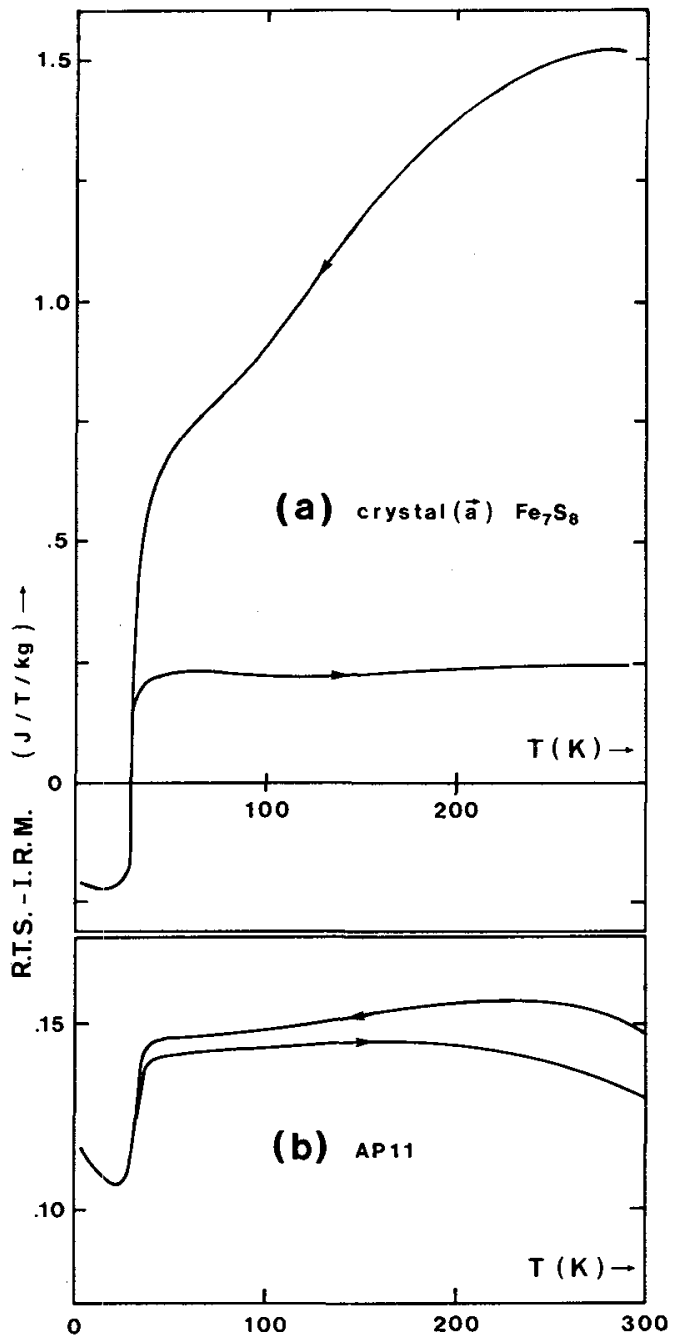

Fig. 2. - Zero field thermal variation of the IRM, (a): $\Gamma_{7} \mathrm{~S}_{8}$ single crystal (after saturation on easy a axis), (b): $\therefore$ P11 schist sample $\left(3 \% \mathrm{Fe}_{7} \mathrm{~S}_{8}\right)$. values $\left(1 \_10 \mathrm{~J} / \mathrm{cm}^{3}\right)$ and do'nt change too much across $30 \mathrm{~K}$, but $K_{1}$ and $K_{2}$ are mainly concerned. The observed variations would then be due to a change in the $J_{\mathrm{s}}$ direction associated with a change of the in-plane easy axis. In fact, the situation is somewhat complicated by the existence of twins and at least three inequivalent iron sites as seen on Mössbauer spectra [3].

On another hand, the analogy with the Verwey transition of magnetite is strongly supported by the associated electrical conductivity anomaly [6] and our observation of a self-reversal of the single crystal remanent magnetization [11]. A change in the electronic state and corelated atoms displacements are not to be excluded.

In conclusion, the $30 \mathrm{~K}$ transition in $\mathrm{Fe}_{7} \mathrm{~S}_{8}$ requires much more experimental investigations for its understanding and some of them are in progress, but it can already be used, by the RTS-IRM study, as the first reliable characterization method of monoclinic pyrrhotite in rock magnetism.

[1] Bertaut, F., Acta Crystallogr. 6 (1953) 557.

[2] Sidhu, S., Heaton, L., Mueller, M. H., J. Appl. Phys. 30 (1959) 1323.

[3] Levinson, L. M., Treves, O., J. Chem. Solids 29 (1968) 2227.

[4] Pauthenet, R., C.R. Acad. Sci. 234 (1952) 2261.

[5] Bin, M., Pauthenet, R., J. Appl. Phys. 34 (1963) 1161.

[6] Besnus, M. J., Meyer, A. J. P., Int. Conf. Magnetims (Nottingham) 1964, p. 507.

[7] Besnus, M. J., Thesis, Strasbourg (1966).

[8] Grönvold, F., Westrum, E. F., Chan, C., J. Chem. Phys. 30 (1959) 528.

[9] Rochette, P., Thesis, Grenoble (1988).

[10] Adachi, K., Sato, J. Appl. Phys. 39 (1968) 1343.

[11] Ozima, M., Ozima, M., Akimoto, S., J. Geomagn. Geoelectr. 16 (1964) 165. 